\title{
Manajemen Kualitas Data dan Informasi dengan Sistem Informasi untuk Meningkatkan Kinerja Operasional Pabrik PT. Sari Aditya Loka 2
}

\author{
Ahmad Fahmi Karami \\ Magister Teknik Informatika Universitas Islam Indonesia \\ e-mail: a.fahmi.karami@gmail.com
}

\begin{abstract}
Organizational performance depends on strategic decisions taken by stakeholders in the organization, where strategic decisions of stakeholders depend on the quality of data and information available to the organization. Data and information quality called good when the data and quality has criterias that suits for users of data and information, where data and information user need on the organization will be different according to their aim and objectives, so that the criteria of data quality and information is not universal. Palm oil mill PT. Sari Aditya Loka 2 (SAL 2) improves the quality management of data and information by utilizing information systems to produce good quality data and information and help improve the organization's performance. This research was conducted to know data and information quality management at PT. SAL 2 in producing data and information, and its contribution on the mill performance using interview methods with those who have a role in the implementation of data quality and information management, observation, and document management related to factory performance. This research resulted findings that still in the implementation of data quality and information management there are still procedures that are not undertaken, so the result of data and information not entirely suits with the user wishes. Although the procedure has not been fully implemented, using data and information production has helped data and information users in decision making and succeeded in lowering the mill breakdown by $0.10 \%$.
\end{abstract}

Keywords : Breakdown, Data and Information Quality, Organizational Performance, Management.

Abstrak

Performa sebuah organisasi bergantung kepada keputusan strategis yang diambil oleh pemangku kepentingan pada organisasi, keputusan strategis dari pemangku kepentingan bergantung terhadap kualitas data dan informasi yang ada pada organisasi. Kualitas data dan informasi yang baik adalah yang memiliki kriteria sesuai dengan keinginan pengguna data dan informasi tersebut sehingga data dan informasi bisa digunakan. Keinginan pengguna terhadap kriteria data dan informasi pada tiap-tiap organisasi akan berbeda sesuai kebutuhannya dan tujuannya, sehingga kriteria kualitas data dan informasi tidak bersifat universal. Pabrik PT. Sari Aditya Loka 2 (SAL 2) melakukan perbaikan manajemen kualitas data dan informasi dengan memanfaatkan sistem informasi untuk dapat menghasilkan data dan informasi yang berkualitas baik dan membantu meningkatkan performa organisasi. Penelitian dilakukan untuk mengetahui manajemen kualitas data dan informasi pada pabrik PT. SAL 2 dalam menghasilkan data dan informasi, dan kontribusi dari data dan informasi yang dihasilkan terhadap performa pabrik menggunakan metode wawancara dengan orang-orang yang mempunyai peran dalam implementasi manajemen kualitas data dan informasi, observasi, dan penelurusan dokumen yang terkait kinerja pabrik. Penelitian ini menghasilkan temuan bahwa masih dalam pelaksanaan manajemen kualitas data dan informasi masih terdapat prosedur yang tidak dijalani, sehingga hasil data dan informasi belum seluruhnya sesuai dengan keinginan pengguna. Meskipun prosedur belum seluruhnya dijalani, penggunaan hasil data dan informasi telah membantu pengguna data dan informasi dalam pengambilan keputusan dan berhasil menurunkan breakdown pabrik sebesar $0,10 \%$. 
Kata kunci: Breakdown, Kualitas data dan informasi, Manajemen, Performa Organisasi

\section{PENDAHULUAN}

Indonesia adalah penghasil Crude Palm Oil (CPO) terbesar didunia. PT. Sari Aditya Loka 2 (PT. SAL 2) adalah pabrik pengolahan kelapa sawit dengan hasil CPO dengan kapasitas olah 60 ton Tandan Buah Segar (TBS) per jam. Proses produksi CPO pada pabrik PT. SAL 2 dapat berlangsung selama 24 jam setiap hari, bergantung kepada suplai TBS yang dikirimkan ke pabrik, sehingga setiap mesin dituntut agar selalu dalam kondisi prima agar efektifitas produksi dapat tercapai. Salah satu indikator efektifitas adalah ketersedian atau kesiapan pabrik untuk proses produksi. Tahun 2013, breakdown pabrik PT. SAL 2 mencapai 0,20\% dan pada tahun 2014 mencapai 0,26\%.

Analisis penyebab terjadinya breakdown adalah kurangnya data dan informasi yang diperoleh bagian maintenance pabrik PT. SAL 2 terhadap kondisi nyata mesinmesin yang menyebabkan tidak tepatnya keputusan yang diambil. Pabrik PT. SAL 2 melakukan perbaikan manajemen data dan informasi dengan memanfaatkan teknologi informasi, yaitu mengimplementasikan Operator Maintenance System (OMS) pada Desember 2014 sebagai upaya dalam mendapatkan data dan informasi yang baik sehingga pengambilan keputusan menjadi tepat dan dapat meningkatkan kinerja operasional.

Efektifitas dan efisiensi implementasi sistem informasi dapat dilihat melalui kualitas data dan informasi yang dihasilkan oleh sistem tersebut. Sheng \& Mykytyn menyatakan, kualitas data dan informasi yang baik mempunyai pengaruh penting dalam pelayanan, produk, operasional dan keputusan bisnis [1]. Sebaliknya kualitas data dan informasi yang buruk mengakibatkan ketidakpuasan pelanggan, meningkatnya biaya operasional, keputusan bisnis yang tidak efektif, dan mengurangi kemampuan untuk membuat dan melaksanakan strategi. Strong et al. dalam Lee dan Strong menyatakan bahwa tujuan pengolahan data adalah untuk menghasilkan data yang dapat dipakai oleh penggunanya [2]. Kualitas data dan informasi yang baik adalah data yang tepat kebutuhannya untuk digunakan penggunanya. Penelitian ini ditujukan untuk melakukan evaluasi terhadap manajemen kualitas data dan informasi yang dihasilkan oleh sistem informasi yang telah diimplementasikan oleh pabrik PT. SAL 2.

Beberapa penelitian mengenai hubungan kualitas data dan informasi dengan performa organisasi dari berbagai disiplin ilmu telah dilakukan, Mäkelä [3] meneliti bahwa kualitas data dan informasi tata ruang pada Geographic Information System (GIS) dapat digunakan untuk pengambilan keputusan pada organisasi.

Kemudian, Masayna et al. [4] melakukan penelitian untuk memverifikasi framework yang menghubungkan kualitas data dan informasi dengan Key Performance Indicator (KPI) organsisasi. Penelitian menggunakan metode survei dan studi kasus dengan wawancara. Peneliti menyatakan bahwa KPI sangat penting untuk manajemen pengambilan keputusan dan diandalkan oleh semua tingkat organisasi sebagai ukuran keberhasilan dalam mencapai sebuah hasil. Pencapaian keberhasilan didukung dengan mengidentifikasi kualitas data dan informasi yang bernilai dan beresiko tinggi untuk memberikan keyakinan dalam pengambilan keputusan.

Gorla et al. [5] dalam penelitiannya yang mengeksplorasi dampak antara kualitas sistem informasi dalam penelitiannya, kualitas sistem informasi terdiri dari (1) kualitas sistem, (2) kualitas data dan informasi, dan (3) kualitas layanan terhadap organisasi. Hasil penelitian menunjukkan bahwa, secara keseluruhan, kualitas sistem informasi memiliki 
pengaruh positif yang signifikan pada dampak organisasi baik secara langsung maupun tidak langsung.

\section{METODOLOGI PENELITIAN}

\subsection{Pengumpulan Data}

Jenis penelitian adalah penelitian kualitatif dengan pendekatan interpretif. Ludigdo,menekankan bahwa penelitian interpretif dilakukan untuk memahami realitas dunia apa adanya [6]. Metode interpretif digunakan karena data yang digunakan berdasarkan perspektif (sudut pandang) dan pengalaman informan. . Untuk mendapatkan gambaran manajemen kualitas data dan informasi, peneliti melakukan pengumpulan data dengan wawancara langsung yang dilakukan secara semi terstruktur, yaitu dengan membuat panduan daftar pertanyaan wawancara yang bersifat terbuka (wawancara dengan jawaban terbuka/tidak ada batasan). Terdapat 19 responden yang diwawancara sesuai dengan peran masing-masing pada manajemen kualitas data dan informasi di pabrik PT. SAL 2. Selain melakukan wawancara, penelitian ini juga menggunakan data lain yaitu observasi penggunaan SI, dan melakukan penelusuran dokumen-dokumen terkait operasional Pabrik PT. SAL 2.

\section{2 Konsep Teori}

\section{2.1 Manajemen Kualitas Data dan informasi}

Manajemen kualitas data dan informasi adalah pembentukan dan pemberian peran, tanggung jawab, ketentuan, dan prosedur terkait pengumpulan, pemeliharaan, penyebaran, pengaturan terhadap data [7]. Wang menyebutkan empat peran dalam manajemen kualitas data dan informasi yaitu (1) Pemberi Informasi, orang-orang yang membuat atau mengumpulkan data, (2) Produsen Informasi, orang-orang yang mengembangkan, mendesain, memelihara data dan infrastruktur sistem, (3) Pengguna informasi, orang-orang yang menggunakan data dan informasi, (4) Manajer Informasi, orang-orang yang bertanggung jawab atas pengelolaan seluruh proses produksi data dan informasi [8]. Wang menyatakan, Life-Cycle manajemen kualitas data dan informasi adalah alat yang digunakan secara terus menerus oleh organisasi untuk memastikan data dan informasi yang dihasilkan selalu mempunyai kualitas yang tinggi. Life-Cycle manajemen kualitas data dan informasi memiliki empat tahap yaitu define, measure, analyze, dan improve. Tujuan manajemen kualitas data dan informasi adalah untuk menghasilkan data yang akan digunakan oleh pengguna data. Data dan informasi yang berkualitas tinggi didefinisikan sebagai data yang cocok untuk digunakan (fit to use) oleh penggunanya (lihat tabel 1). 
Tabel 1. Definisi Kualitas Data dan Informasi [9]

\begin{tabular}{lcc}
\hline \multicolumn{1}{c}{ Peneliti } & $\begin{array}{c}\text { Perspektif } \\
\text { informasi }\end{array}$ & $\begin{array}{c}\text { Perspektif } \\
\text { pengguna }\end{array}$ \\
\hline Wang and Strong (1996) & & $\mathrm{v}$ \\
Kahn and Strong (1998) & $\mathrm{v}$ & \\
Olson (2003) & & $\mathrm{v}$ \\
Keller and Staelin (1987) & & $\mathrm{v}$ \\
Redman (2001) & & $\mathrm{v}$ \\
English (1999) & & $\mathrm{v}$ \\
Brien (1991) & & $\mathrm{v}$ \\
Eppler (2006) & $\mathrm{v}$ & $\mathrm{v}$ \\
Salaün and Flores (2001) & & \\
\hline
\end{tabular}

Setiap organisasi memiliki kebutuhan yang berbeda terhadap kualitas data dan informasi, sehingga tidak ada sebuah model manajemen kualitas data dan informasi yang dapat digunakan secara universal pada organisasi yang berbeda-beda. Organisasi membuat keputusan berdasarkan data dan informasi yang dimiliki. Kelangsungan hidup bisnis bergantung pada data dan informasi yang baik, dan data dan informasi yang baik adalah bergantung pada pendekatan yang efektif oleh organsasi untuk manajemen kualitas data. Secanggih apapun sebuah sistem informasi manajemen data dan informasi yang digunakan, apabila data dan informasi yang dihasilkan tidak sesuai dengan yang diharapkan oleh pengguna data, maka kualitas data dan informasi tidak dapat dimanfaatkan secara maksimal oleh pengguna data untuk melakukan langkah strategis yang berdampak pada peningkatan performa organisasi.

Terdapat lebih dari 200 kriteria kualitas data dan informasi menurut Cervo dan Allen [10], 16 Kriteria dari Wang dan Strong (lihat tabel 2) (1996) adalah salah satu yang pertama dikenalkan dan masih paling berpengaruh.

Tabel 2. Definisi Kualitas Data dan Informasi

\begin{tabular}{|c|c|c|}
\hline No & Kriteria & Definisi \\
\hline 1 & Aksesibilitas & Sejauh mana data dan informasi tersedia, atau dengan mudah dan cepat didapatkan \\
\hline 2 & Kesesuaian jumlah & Sejauh mana jumlah data dan informasi sesuai untuk tugas pengguna \\
\hline 3 & Kepercayaan & Sejauh mana data dan informasi benar dan kredibel \\
\hline 4 & Kelengkapan & Sejauh mana data lengkap, cukup luas dan dalam untuk tugas di tangan \\
\hline 5 & Keringkasan & Sejauh mana data dan informasi disajikan dalam bentuk yang ringkas \\
\hline 6 & Konsistensi & Sejauh mana data dan informasi disajikan dalam format yang baku \\
\hline 7 & Kemudahan manipulasi & $\begin{array}{l}\text { Sejauh mana kemudahan data dan informasi untuk diolah dan digunakan untuk tugas } \\
\text { yang berbeda }\end{array}$ \\
\hline 8 & Bebas dari kesalahan & Sejauh mana data dan informasi benar dan dapat diandalkan \\
\hline 9 & Kemudahan penafsiran & $\begin{array}{l}\text { Sejauh mana data dan informasi menggunakan bahasa, simbol, dan unit yang benar } \\
\text { serta memiliki definisi yang jelas }\end{array}$ \\
\hline 10 & Objektivitas & Sejauh mana data dan informasi tidak berprasangka, dan tidak memihak \\
\hline 11 & Relevansi & Sejauh mana data dan informasi relevan dan membantu untuk tugas pengguna \\
\hline 12 & Reputasi & Sejauh mana sumber dan konten data dan informasi memiliki reputasi \\
\hline 13 & Keamanan & $\begin{array}{l}\text { Sejauh mana akses data dan informasi dibatasi sesuai tingkatannya untuk menjaga } \\
\text { keamanan }\end{array}$ \\
\hline 14 & Ketepatan waktu & Sejauh mana data dan informasi cukup up-to-date untuk tugas pengguna \\
\hline 15 & Kemudahan pemahaman & Sejauh mana data dan informasi mudah dipahami \\
\hline 16 & Nilai tambah & $\begin{array}{l}\text { Sejauh mana data dan informasi menguntungkan dan memberikan keuntungan bagi } \\
\text { penggunaannya }\end{array}$ \\
\hline
\end{tabular}




\subsubsection{Operator Maintenance System (OMS)}

OMS merupakan sistem pengelolaan data dan informasi pada pabrik PT. SAL 2 yang bertujuan mencegah terjadinya deteriorasi (menurunnya kemampuan mesin), dengan mengumpulkan kondisi aktual mesin-mesin. Gejala kerusakan yang terjadi apabila tidak ditangani dengan benar, mesin akan mengalami kerusakan yang menyebabkan kerusakan lainnya . Kegiatan OMS terdiri dari inspeksi mesin, verifikasi hasil inspeksi, dan pelaksanaan perbaikan. Hasil produk dari OMS adalah data dan informasi mesin yang memiliki ketidaksesuaian kondisi, diharapkan data dan informasi OMS yang dihasilkan masih berupa gejala pada mesin sehingga dapat digunakan oleh tim maintenance untuk menentukan tindakan pada mesin tersebut dalam mencegah terjadinya breakdown. Breakdown atau lebih dikenal pada umumnya downtime, adalah salah satu parameter dari tiga parameter pengukuran performa organisasi yang popular diperkenalkan oleh Nakajima pada tahun 1980an bernama Overall Equipment Effectiveness (OEE). OEE mengukur dan mengidentifikasi kehilangan atau kerugian saat produksi dengan ukuran yang dinamakan availability, performance, dan quality rate [12]

Gambar 1 mengilustrasikan proses produksi data dan informasi dimana awalnya mempunyai empat unit data (unit data 1-4) dari hasil inspeksi operator masing-masing stasiun yang kemudian menjadi satu unit data (unit data 5) setelah dilakukan pengecekan kualitas dengan cara verifikasi oleh supervisor. Data akan tersimpan kemudian diproses untuk dipisahkan hasil inspeksi mesin yang tidak sesuai standar (unit data 6) yang diteruskan ke pengguna data yaitu staf dan supervisor maintenance.

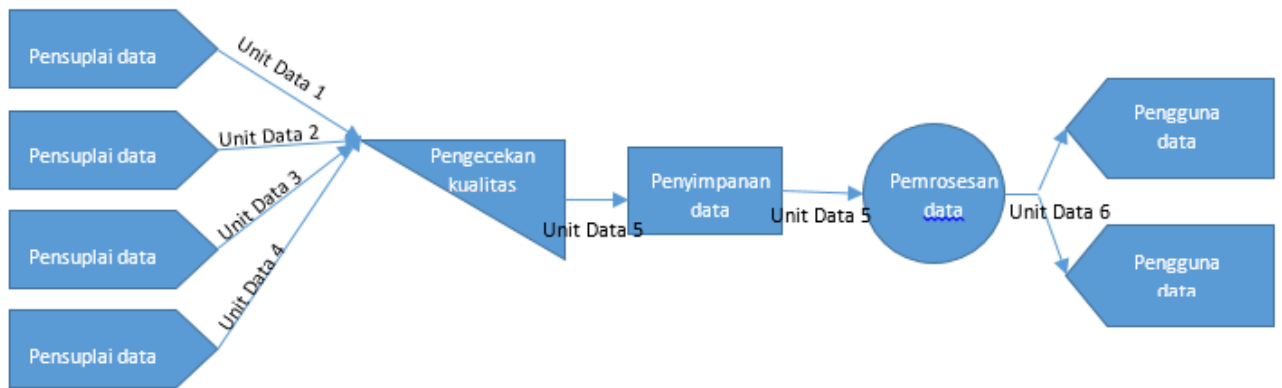

\section{Gambar 1. Ilustrasi Proses Produksi Data Dan Informasi}

Data dan informasi yang berkualitas tinggi akan memberikan kemudahan bagi manajemen dalam proses pengambilan keputusan. Sugumaran dan De Groote (2011) dalam [9] mendefinisikan keputusan adalah "pilihan yang dibuat diantara dua alternatif atau lebih". Kingma (1996) dalam Fisher, et al (2003) menyatakan "pengambilan keputusan adalah respon dari sebuah masalah yang dimana terdapat beberapa pilihan alternatif".

Lunenburg (2010) dalam Samitsch menyebutkan tiga komponen dalam proses pengambilan keputusan : pertama, sebuah pilihan harus diambil dari beberapa pilihan yang ada. Kedua, pengetahuan tentang bagaimana keputusan yang telah dibuat harus diperoleh. Ketiga, untuk mendapatkan keputusan akhir, proses pengambilan keputusan harus melibatkan tujuan dan target yang ingin dicapai [9].

Samitch menyatakan bahwa kualitas data dan informasi merupakan salah satu faktor yang memberikan efektifitas dalam pengambilan keputusan, akan tetapi tidak semua dimensi kualitas data dan informasi berkontribusi pada pengambilan keputusan [9]. M. Ge menyatakan dalam penelitiannya bahwa bebas dari kesalahan dan kelengkapan pada data dan informasi merupakan dua penentu dalam pengambilan keputusan yang 
tepat, sehingga organisasi dianggap tidak perlu melakukan perbaikan kualitas data dan informasi secara menyeluruh untuk meningkatkan efektifitas pengambilan keputusan [14]. Mengacu pada kebutuhan akan kualitas data dan informasi berdasarkan pada fit-foruse $\mathrm{Li}$ et al dalam penelitiannya menemukan bahwa dimensi kualitas data dan informasi yang sangat mempengaruhi manajemen forecast berbantuan sistem informasi adalah integritas pengolahan data dan informasi yang mempunyai kriteria bebas dari kesalahan dan terpercaya [15]. Beberapa pendapat peneliti tentang kriteria kualitas data dan informasi yang berpengaruh pada pengambilan keputusan telah dirangkum (lihat tabel 3), huruf "v" menunjukkan peneliti menyatakan kriteria pada kolom tersebut berpengaruh terhadap pengambilan keputusan.

Tabel 3. Kriteria Kualitas Data dan Informasi yang berdampak pada Pengambilan Keputusan

\begin{tabular}{|c|c|c|c|c|c|}
\hline Peneliti & Bebas dari Kesalahan & Kelengkapan & kepercayaan & Ketepatan Waktu & Konsistensi \\
\hline Ge (2009) & $\mathrm{v}$ & $\mathrm{v}$ & & & \\
\hline Li et al. (2012) & $\mathrm{v}$ & & $\mathrm{v}$ & & \\
\hline Jakli et al. (2011) & & & & $\mathrm{V}$ & $\mathrm{V}$ \\
\hline
\end{tabular}

Penggunaan sistem informasi OMS untuk efektifitas dan efisiensi kegiatan inspeksi mesin yang dilakukan oleh operator dan menghasilkan kondisi-kondisi aktual pada bagian-bagian mesin, terutama bagian mesin yang terdapat gejala ketidaksesuaian. Haruskah dilakukan perbaikan saat itu juga? bisakah menunggu sampai waktu yang telah ditentukan? Pengambil keputusan dapat menggunakan intuisi dalam menyelesaikan sebuah masalah, akan tetapi dalam menyelesaikan masalah, pengambil keputusan membutuhkan data dan informasi yang baik untuk mendukung pengambilan keputusan. Semakin tinggi kualitas data dan informasi yang didapatkan, semakin cepat dan tepat keputusan yang diambil manajemen untuk melakukan pencegahan breakdown.

\section{HASIL DAN PEMBAHASAN}

Manajemen kualitas data dan informasi menggunakan SI OMS diterapkan untuk mendapatkan data dan informasi yang lebih baik dari sebelumnya terhadap gejala ketidaksesuaian pada mesin pabrik PT. SAL 2. Dari sepuluh stasiun yang ada, empat stasiun telah terimplementasi OMS yaitu stasiun sterilizer, press, klarifikasi, dan kernel. Setelah implementasi, terdapat tujuh kriteria kualitas data dan informasi yang meningkat, sementara dua kriteria tetap. Terdapat tujuh kriteria yang tidak diatur pada OMS (lihat tabel 4).

Tabel 4. Kriteria data dan informasi setelah implementasi OMS

\begin{tabular}{clccc}
\hline No & \multicolumn{1}{c}{ Kriteria } & Meningkat & Tetap & Tidak ada \\
\hline 1 & Aksesibilitas & v & - & - \\
2 & Kesesuaian jumlah & v & - & - \\
3 & Kepercayaan & - & - & v \\
4 & Kelengkapan & v & - & - \\
5 & Keringkasan & - & - & v \\
6 & Konsistensi & - & v & - \\
7 & Kemudahan manipulasi & - & - & v \\
8 & Bebas dari kesalahan & v & - & - \\
9 & Kemudahan penafsiran & v & - & - \\
10 & Objektivitas & - & - & v \\
11 & Relevansi & - & v & - \\
12 & Reputasi & - & - & v \\
13 & Keamanan & v & - & - \\
14 & Ketepatan waktu & v & - & - \\
\hline
\end{tabular}




\begin{tabular}{lllll}
\hline 15 & Kemudahan pemahaman & - & - & $\mathrm{v}$ \\
16 & Nilai tambah & - & - & $\mathrm{v}$ \\
\hline
\end{tabular}

Kriteria aksesibilitas atau kemampuan untuk akses data dan informasi meningkat dari sebelumnya hanya bisa diakses dikantor proses, menjadi lebih mudah dan cepat dengan kemampuan akses di area-area yang sudah dilengkapi dengan jaringan wi-fi, yaitu di stasiun-stasiun yang telah mengimplementasikan OMS, kantor proses, dan kantor maintenance.

Kriteria kesesuaian jumlah data dan informasi meningkat dari sebelumnya jumlah data tidak diketahui karena pelaporan berdasarkan temuan dilapangan, menjadi lebih baik pada empat stasiun dengan penjadwalan inspeksi pada 68 mesin, dan 243 bagian.

Kriteria kepercayaan tidak diatur sebelum dan sesudah implementasi OMS pada pabrik PT. SAL 2.

Kriteria kelengkapan data dan informasi meningkat dari sebelumnya hanya berupa tanggal pelaporan dan bagian mesin yang ditemukan gejala abnormal menjadi tanggal pelaporan, nama sta-siun, nama mesin, bagian mesin, kondisi mesin, dan catatan.

Kriteria keringkasan tidak diatur sebelum dan sesudah implementasi OMS pada pabrik PT. SAL 2.

Kriteria konsistensi data dan informasi dengan adanya implementasi OMS tidak ada perubahan. Sebelum dan sesudah implementasi data dan informasi sama-sama menggunakan format yang ba-ku, hanya bentuk format yang berbeda antara sistem lama dan baru.

Kriteria kemudahan manipulasi tidak diatur sebelum dan sesudah implementasi OMS pada pabrik PT. SAL 2

Kriteria bebas dari kesalahan sebelum implementasi OMS, belum ada. Setelah implementasi OMS menambahkan proses verifikasi oleh supervisi proses untuk mencegah kesalahan saat inspeksi oleh operator sehingga data dan informasi yang dihasilkan akurat.

Kriteria kemudahan penafsiran dipermudah dengan implementasi OMS, dimana OMS memiliki daftar nama stasiun, mesin, dan bagian secara lengkap sehingga menghilangkan kesalahan dalam penulisan nama-nama mesin yang dapat menimbulkan kesulitan dalam menafsirkan data dan informasi, meskipun kolom catatan tetap diisi manual sehingga masih memungkinkan terdapat kesalahan dalam penulisan. Sebelum implementasi OMS, seluruh data dan informasi ditulis manual sehingga memungkinkan terdapat kesalahan dalam penulisan.

Kriteria objektifitas tidak diatur baik sebelum dan sesudah implementasi OMS pada pabrik PT. SAL 2.

Kriteria relevansi sudah sesuai, karena tujuan dari implementasi OMS yaitu memproduksi data dan informasi kondisi aktual mesin-mesin pabrik PT. SAL 2 untuk menurunkan breakdown.

Kriteria reputasi tidak diatur baik sebelum dan sesudah impelentasi OMS pada pabrik PT. SAL 2.

Kriteria keamanan belum terdapat sebelum implementasi OMS, karena masih menggunakan tulisan tangan pada buku yang dapat diakses oleh siapa saja. Setelah implementasi OMS, setiap pengguna OMS diberikan username dan password untuk akses kedalam aplikasi, dimana tiap-tiap pengguna mempunyai batasan untuk mengakses fiturfitur yang ada pada akses aplikasi, sesuai dengan wewenang atau jabatan pengguna tersebut.

Kriteria ketepatan waktu sebelum implementasi OMS tidak diatur, sehingga dapat terjadi kerusakan tiba-tiba apabila terdapat keabnormalan mesin yang tidak dilaporkan oleh operator. Setelah implementasi OMS, setiap mesin mempunyai frekwensi inspeksi, 
yaitu harian, mingguan, bulanan, tiga bulanan, dan enam bulan. Sehingga keterlambatan laporan kondisi mesin dapat dihindari. Selain ketepatan waktu dalam pelaporan kondisi mesin, dengan adanya OMS data dan informasi dari mesin yang sudah diinspeksi dapat langsung dapat diakses oleh pengguna.

Kriteria kemudahan pemahaman tidak diatur baik sebelum dan sesudah impelentasi OMS pada pabrik PT. SAL 2.

Kriteria nilai tambah tidak diatur baik sebelum dan sesudah impelementasi OMS pada pabrik PT. SAL 2.

Dalam pelaksanaan OMS, terdapat enam ketidaksesuaian prosedur yang terjadi sehingga terdapat data dan informasi yang tidak sesuai dengan kriteria yang diinginkan (lihat tabel 5).

Tabel 5. Ketidaksesuaian Prosedur Pelaksanaan OMS

\begin{tabular}{lll}
\hline No & \multicolumn{1}{c}{ Ketidaksesuaian } & \multicolumn{1}{c}{ Kriteria yang terpengaruhi } \\
\hline 1 & $\begin{array}{l}\text { Operator tidak melaksanakan Inspeksi sesuai } \\
\text { jadwal }\end{array}$ & Ketepatan waktu \\
2 & $\begin{array}{l}\text { Hasil inspeksi Operator tidak sesuai dengan } \\
\text { kondisi aktual }\end{array}$ & Bebas dari kesalahan \\
3 & $\begin{array}{l}\text { Verifikasi hasil inspeksi oleh supervisor } \\
\text { proses tidak dilaksanakan setelah inspeksi } \\
\text { Kolom keterangan bagian dengan status } \\
\text { NOK dari hasil inspeksi operator tidak diisi }\end{array}$ & Kebas dari kesalahan \\
5 & $\begin{array}{l}\text { Kolom keterangan bagian dengan status } \\
\text { NOK dari hasil inspeksi operator } \\
\text { mengandung kata yang tidak baku }\end{array}$ & Kemudahan penafsiran \\
6 & $\begin{array}{l}\text { Data dan informasi hasil inspeksi diambil } \\
\text { dikantor proses }\end{array}$ & Aksesibilitas, Ketepatan waktu \\
\hline
\end{tabular}

Ketidaksesuaian pertama adalah, operator tidak melaksanakan inspeksi sesuai jadwal (lihat gambar 2)

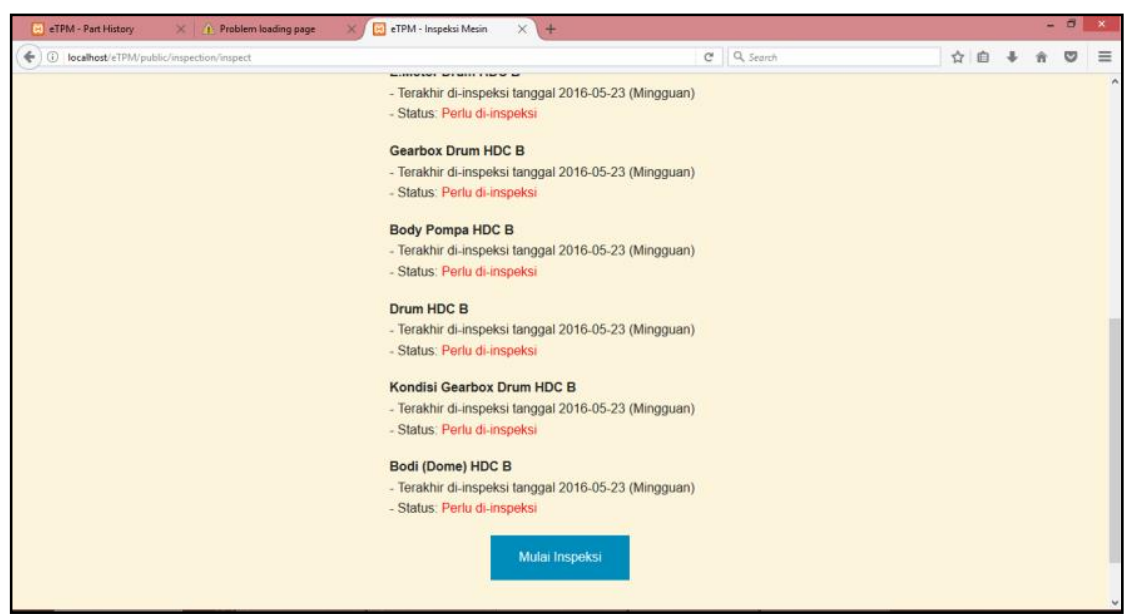

Gambar 2. Contoh Bagian-Bagian Yang Tidak Diinspeksi Tepat Waktu

Inspeksi yang tidak dilakukan tepat waktu membuat data dan informasi kondisi bagian-bagian mesin tersebut tidak terperbaharui dengan kondisi aktual dilapangan sehingga kriteria ketepatan waktu menjadi tidak terpenuhi. Penyebab dari belum sesuainya ketepatan waktu adalah kegiatan inspeksi yang berbarengan dengan proses pengolahan TBS. Manajemen dapat melihat dan melakukan evaluasi terhadap 
pelaksanaan inspeksi dengan memperjelas prosedur yang mengatur waktu pelaksanaan OMS, agar bisa dilakukan tanpa mengurangi atau menghilangkan tugas pokok operator. Hal ini sesuai dengan pendapat Cervo et al, yang menyatakan bahwa permasalahan dalam manajemen kualitas data dan informasi yang muncul yaitu belum adanya prosedur yang mengatur permasalahan tersebut, akan tetapi seiring dengan berjalannya manajemen kualitas data dan informasi, dibutuhkan penambahan prosedur untuk menghilangkan masalah yang muncul [10]. Pembuatan prosedur harus dibarengi dengan evaluasi hasil inspeksi operator, mengingat pelaksanaan OMS bersifat mandatorial. Staf proses selaku penganggung jawab data dan informasi dapat memasukkan pelaksanaan OMS sebagai salah satu key performance indikator (KPI) dari operator, sehingga proses reward and punishment dapat berjalan.

Selain dari prosedur yang diatur dengan baik, pengaturan frekwensi inspeksi bagian-bagian mesin belum dilakukan berdasarkan waktu rata-rata terjadinya ketidaksesuaian pada bagian mesin tersebut atau disebut mean time between failure (MTTF). Penentuan frekwensi berdasarkan MTTF akan menghilangkan waktu yang terbuang untuk melakukan inspeksi bagian mesin berulang-ulang atau mengurangi efektifitas pelaksanaan inspeksi.

Ketidaksesuaian kedua, hasil inspeksi operator tidak sesuai dengan kondisi aktual. Pelaksanaan inspeksi pada bagian-bagian mesin ditujukan untuk mendapatkan kondisi aktual dari mesin tersebut. Hasil dari inspeksi adalah mesin sesuai dengan standar yang ditentukan dilambangkan dengan "OK", dan tidak sesuai dengan standar dilambangkan dengan "NOK". Kesalahan dalam menentukan kondisi aktual mesin terjadi kerena beberapa hal. Pertama, operator melakukan inspeksi dan input kondisi bagian-bagian mesin tidak pada waktu bersamaan, input kondisi bagian-bagian mesin pada aplikasi dilakukan saat tidak melihat kondisi aktual mesin yaitu saat pergantian shift. Jumlah data dan informasi yang diinspeksi sangat banyak sehingga penundaan input memungkinkan terjadinya kesalahan dalam pengisian kondisi aktual bagian mesin. Kedua, operator melakukan inspeksi dengan tergesa-gesa, tidak sesuai dengan petunjuk yang tertera pada aplikasi sehingga terdapat kesalahan dalam menentukan kondisi bagian-bagian mesin. Seperti keadaan pada ketidaksesuaian pertama, manajemen harus memperjelas atau membuat aturan-aturan dalam melaksanakan inspeksi.

Selain penentuan status kondisi mesin, kesalahan pada data dan informasi OMS terletak pada pemilihan kondisi untuk bagian-bagian mesin berstatus NOK saat inspeksi. Kesalahan pemilihan kriteria dikarenakan pengetahuan karyawan mengenai inspeksi bagian-bagian mesin masih kurang. Pengetahuan karyawan dapat ditingkatkan dengan melakukan sosialisasi dan pelatihan secara terus menerus, tidak hanya sekali. Pelatihan dapat dilakukan secara formal maupun informal. Cervo et al., menyatakan bahwa beberapa penelitian menunjukkan pelatihan informal lebih efektif daripada pelatihan formal. Staf dan supervisi proses dapat langsung memberikan pelatihan kepada operator saat pelaksanaan inspeksi. Setelah pelatihan, staf proses harus melakukan evaluasi terhadap kompetensi operator-operator yang melakukan inspeksi [10].

Ketidaksesuaian ketiga, beberapa verifikasi hasil inspeksi oleh supervisor proses tidak dilakukan sesuai prosedur, yaitu tidak dilaksanakan setelah inspeksi. Hal ini dapat menyebabkan adanya hasil inspeksi yang tidak benar, masuk ke data dan informasi OMS dan digunakan oleh staf dan supervisor maintenance. Hal ini sesuai dengan pernyataan Cervo et al. yang menyatakan bahwa masalah dalam manajemen kualitas data dan informasi adalah prosedur yang mengatur sudah ada, tetapi tidak diikuti dan diimplementasikan dengan baik [10]. Penyebab dari keterlambatan proses verifikasi adalah keterbatasan sumber daya manusia, dimana yang dapat melakukan verifikasi hanya supervisor proses. Pabrik PT. SAL 2 hanya mempunyai satu orang supervisor 
proses pada tiap-tiap shiftnya. Banyaknya jumlah data yang harus diverifikasi menjadikan supervisi proses tidak dapat melakukan verifikasi sesuai dengan prosedur. Proses verifikasi bisa dicapai dengan melakukan penambahan verifikator inspeksi yang dapat diambil dari operator yang sudah ditraining, atau melakukan perekrutan SDM dengan kemampuan sesuai yang dibutuhkan. Hal ini sesuai dengan pernyataan Geiger, bahwa diperlukan investasi baik berupa finansial maupun SDM untuk mengatasi permasalahan manajemen kualitas data dan informasi [7].

Ketidaksesuaian keempat, kolom catatan bagian dengan status NOK tidak diisi (lihat gambar 3)

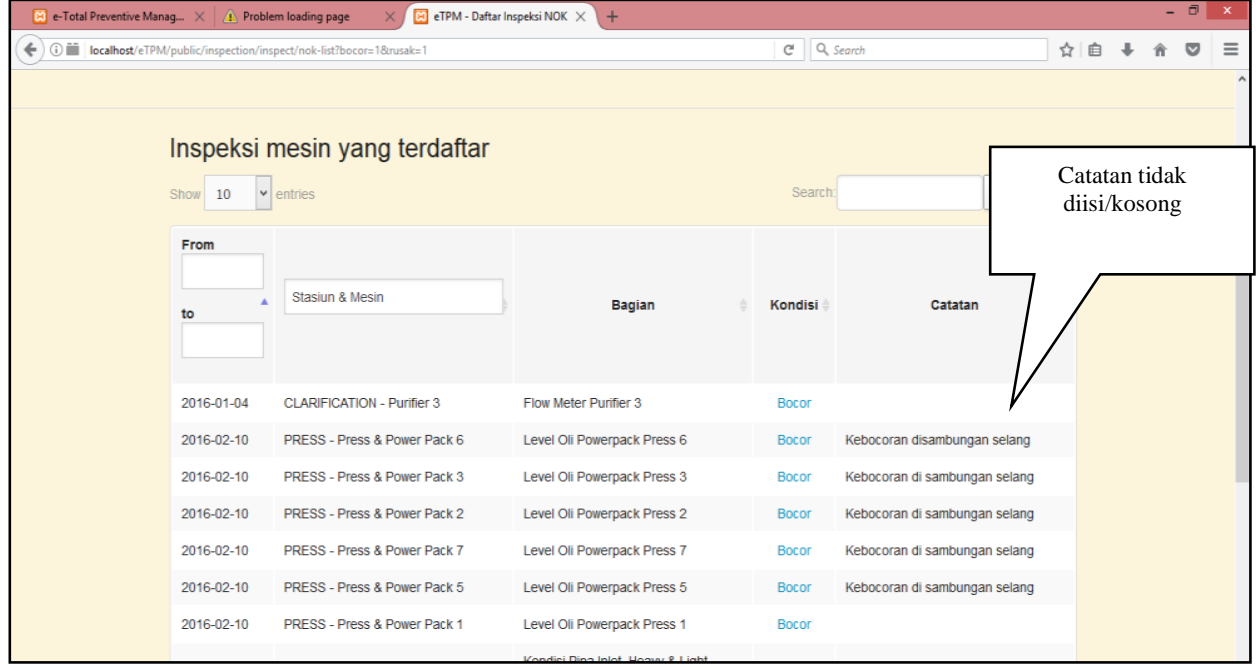

Gambar 3. Contoh Tampilan Daftar item NOK

Penyebab dari kosongnya catatan untuk bagian berstatus NOK masih berupa waktu yang belum ditetapkan, sehingga pengisian yang dilakukan tidak sesuai prosedur yang telah ditentukan. Sama seperti ketidaksesuaian pertama, evaluasi waktu pelaksanaan dibutuhkan agar inspeksi terlaksana sesuai prosedur.

Ketidaksesuaian kelima, kolom catatan bagian mesin dengan status NOK mengandung kata yang tidak baku. Kesalahan penulisan keterangan dapat menyulitkan pengguna data dan informasi dalam membaca dan menyebabkan kesalahan pengguna dalam menafsirkan. Perlu ditambahkan fitur pada aplikasi untuk melakukan koreksi otomatis untuk istilah-istilah bahasa inggris yang sering digunakan pada pabrik PT. SAL 2 untuk dapat mengeliminasi kemungkinan penulisan kalimat yang tidak baku.

Ketidaksesuaian keenam, data dan informasi hasil inspeksi diambil dikantor proses. Kesulitan dalam akses data dan informasi disebabkan oleh wifi yang sering rusak sehingga data dan informasi tidak bisa diakses secara nirkabel. Penyebab rusaknya router adalah kesalahan dalam menggunakan jenis router. Router yang digunakan adalah tipe indoor, sehingga tidak tahan terhadap air mengingat kondisi bangunan pabrik PT. SAL 2 berbentuk semi-outdoor. Hal ini juga dapat disebabkan kurangnya pengetahuan organisasi mengenai alat kerja yang berhubungan dengan teknologi informasi. Untuk mencapai hasil dari kriteria ini diperlukan peran produsen informasi dalam manajemen kualitas data dan informasi yang belum ada di pabrik PT. SAL 2. Produsen informasi bertugas mengembangkan, mendesain, memelihara data dan infrastruktur sistem hal ini sesuai dengan empat peran dalam manajemen kualitas data dan informasi oleh Wang [8]. Produsen informasi berkompeten untuk memilih insfrastruktur OMS dalam hal ini router wifi. Berdasarkan pernyataan responden bahwa belum ada SDM yang berkompeten untuk 
produsen informasi, maka pabrik PT. SAL 2 dapat melakukan pelatihan pada SDM yang sudah ada, atau melakukan perekrutan SDM dengan kemampuan sesuai yang dibutuhkan.

Meskipun hasil produksi data dan informasi belum sepenuhnya konsisten dan memenuhi kriteria, data dan informasi tetap digunakan oleh pengguna data dan informasi. Dari lima kriteria yang masih terdapat ketidaksesuaian, kriteria yang berpengaruh terhadap pengambilan keputusan mengenai tindakan yang dilakukan terhadap laporan ketidaksesuaian kondisi mesin adalah ketepatan waktu, bebas dari kesalahan, dan kelengkapan. Data dan informasi yang tidak lengkap dapat disikapi pengguna data dengan melakukan konfirmasi terhadap supervisi proses untuk menanyakan rincian mengenai ketidaksesuaian yang terjadi. Data dan informasi yang tidak akurat akan diketahui setelah dilakukan pengecekan ke mesin terkait, apabila tidak ditemukan kerusakan maka mekanik akan melaporkan ke supervisi maintenance untuk mendapatkan pekerjaan lain. Data dan informasi yang tidak tepat waktu tidak tersajikan ke data untuk bagian maintenance, sehingga tidak dapat dilakukan tindakan perbaikan dan berpotensi menyebabkan terjadinya breakdown.

Peningkatan kinerja yang diharapkan oleh pabrik PT. SAL 2 adalah penurunan terhadap breakdown pabrik. Data breakdown pabrik PT. SAL 2 menunjukkan adanya penurunan tahun 2014 dibandingkan dengan tahun 2015 sebesar 0,10\%, jika dirubah sesuai OEE, availability pabrik PT. SAL2 pada tahun 2015 adalah 99,84\%. Implementasi OMS yang belum dilakukan ke seluruh stasiun pabrik PT. SAL 2 menjadikan kurangnya akurasi dalam menentukan pengaruh implementasi OMS terhadap penurunan breakdown pabrik, sehingga availability belum bisa mencapai 100\%. Data menunjukkan terdapat stasiun yang menyumbangkan breakdown dan belum terimplementasi OMS yaitu stasiun threshing, boiler, dan water treatment. Stasiun sterilizer, press, klarifikasi, dan kernel yang sudah terimplementasi OMS mengalami penurunan breakdown pada tahun 2015.

Selain data breakdown pabrik, pabrik PT. SAL 2 juga mempunyai data breakdown mesin. Data menunjukkan bahwa terjadi penurunan jumlah breakdown mesin sebesar 295 kejadian pada stasiun yang sudah mengimplementasikan OMS pada tahun 2015. Pabrik PT. SAL 2 perlu untuk mengimplementasikan mesin-mesin yang menyebabkan breakdown pabrik, sehingga dapat dirasakan manfaat dari implementasi OMS sesuai dengan tujuan yang diinginkan.

\section{KESIMPULAN} berikut :

Dari pembahasan dapat ditarik beberapa kesimpulan diantaranya adalah sebagai

Manajemen kualitas data dan informasi OMS bertujuan untuk menghasilkan data dan informasi bagian-bagian mesin yang tidak sesuai dan dapat menyebabkan terjadinya breakdown pabrik dan breakdown mesin. Kriteria data dan informasi dari hasil OMS adalah Aksesibilitas, kesesuaian jumlah, kelengkapan, konsistensi, bebas dari kesalahan, kemudahan penafsiran, relevansi, keamanan, dan ketepatan waktu.

Pelaksanaan OMS masih belum konsisiten, terdapat enam ketidaksesuaian yang ada pada OMS, dan menyebabkan kriteria data dan informasi tidak terpenuhi yaitu operator tidak melaksanakan Inspeksi sesuai jadwal, hasil inspeksi operator tidak sesuai dengan kondisi aktual, verifikasi hasil inspeksi oleh supervisor proses tidak dilaksanakan setelah inspeksi, kolom keterangan bagian dengan status NOK dari hasil inspeksi operator tidak diisi, kolom keterangan bagian dengan status NOK dari hasil inspeksi operator mengandung kata yang tidak baku, dan data dan informasi hasil inspeksi diambil dikantor proses. 
Kriteria kualitas data dan informasi yang berpengaruh terhadap pengambilan keputusan menurut pengguna adalah bebas dari kesalahan, kelengkapan, dan ketepatan waktu.

Stasiun-stasiun yang telah terimplementasi OMS, mengalami penurunan baik breakdown pabrik maupun breakdown mesin, meskipun masih terdapat breakdown pada stasiun yang terimplementasi disebabkan belum terpenuhi prosedur pelaksanaan OMS secara konsisten.Kesimpulan harus mengindikasi secara jelas hasil-hasil yang diperoleh, kelebihan dan kekurangannya, serta kemungkinan pengembangan selanjutnya.

\section{SARAN}

Adapun saran untuk penelitian manajemen kualitas data dan informasi selanjutnya adalah sebagai berikut :

1. Penelitian selanjutnya dapat memperbanyak jumlah pengguna hasil data dan informasi, sehingga kriteria kualitas data dan informasi yang berpengaruh terhadap pengambilan keputusan terkait performa organisasi lebih beragam.

2. Perlu dilakukan penelitian terhadap organisasi lain yang bergerak dibidang agro industri selain pengolahan kelapa sawit untuk dapat dilakukan perbandingan kualitas data dan informasi yang dihasilkan.

3. Perlu dilakukan penelitian terhadap organisasi lain yang bergerak dibidang manufaktur untuk dapat dilakukan perbandingan kualitas data dan informasi yang dihasilkan.

\section{DAFTAR PUSTAKA}

[1] Y. P. Sheng and P. P. Mykytyn, "Information Technology Investment and Firm Performance: A Perspective of Data Quality," Seventh Int. Conf. Inf. Qual., pp. 132-141, 2002.

[2] Y. W. Lee and D. M. Strong, "Knowing-Why About Data Processes and Data Quality," J. Manag. Inf. Syst., vol. 20, no. 3, pp. 13-39, 2003.

[3] J. M. Mäkelä, "The Impact of Spatial Data Quality on Company's Decision Making," Int. Arch. Photogramm. Remote Sens. Spat. Inf. Sci., vol. 34, no. XXX, 2006.

[4] V. Masayna, A. Koronios, J. Gao, and M. Gendron, "Data Quality and KPIs : A Link to be Established," in The 2nd World Congress on Engineering Asset Management (EAM) and The 4th International Conference on Condition Monitoring, 2007, pp. 1377-1386.

[5] N. Gorla, T. M. Somers, and B. Wong, "Organizational impact of system quality, information quality, and service quality," J. Strateg. Inf. Syst., vol. 19, pp. 207228, 2010.

[6] U. Ludigdo, “Asumsi Dasar Paradigma Interpretive,” 2013.

[7] J. J. Geiger, "Data quality management: the most critical initiative you can implement," SUGI 29 Proc., pp. 1-14, 2004.

[8] R. Y. Wang, "Total Data Quality Management," Commun. ACM, vol. 41, no. 2, 1998.

[9] C. Samitsch, Data Quality and its Impacts on Decision-Making. 2014.

[10] D. Cervo, M. Allen, D. H.Cervo, and M. Allen, "Data Quality Management," in Master Data Management in Practice: Achieving True Customer MDM, no. May, 2011, pp. 111-140.

[11] R. W. Wang and D. M. Strong, "Beyond Accuracy: What Data Quality Means to 
Data Consumers.," J. Manag. Inf. Syst., vol. 12, no. 4, p. 5, 1996.

[12] L. M.-Y. A. Pintelon and P. N. Muchiri, "Performance measurement using overall equipment effectiveness (OEE): Literature review and practical application discussion," Int. J. Prod. Res., vol. 46, no. 13, pp. 3517-3535, 2008.

[13] C. W. Fisher, I. Chengalur-Smith, and D. P. Ballou, "Quality Information in Decision Making The Impact of Experience and Time on the Use of Data Quality Information in Decision Making," Inf. Syst. Res., vol. 14, no. August 2015, pp. 170-188, 2003.

[14] M. Ge, "Information Quality Assessment and Effects on Inventory Decisionmaking," Dublin City University, 2009.

[15] C. Li, G. F. Peters, V. J. Richardson, and M. W. Watson, "The Consequences Of Information Technology Control Weaknesses On Management Information Systems: The Case Of Sarbanes-Oxley Internal Control Reports," Mis Q., vol. 36, no. 1, pp. 179-203, 2012.

[16] J. Jakli, A. Popovi, and P. S. Coelho, "The Impact of Quality Information Provided by Business Intelligence Systems on the Use of Information in Business Processes," in ENTERprise Information Systems, 2011, pp. 158-167. 